\title{
How to Integrate Confucianism into Art Design Education in Colleges and Universities
}

\author{
Li Minyan ${ }^{1, a}$, Li Minfang ${ }^{1, b}$ \\ ${ }^{1}$ Jiangxi Science \& Technology Normal University, Nanchang, Jiangxi, 330013, China \\ a724390219@qq.com, b3910546@qq.com
}

Keywords: Confucianism; art design education; college students

\begin{abstract}
On the basis of analyzing the value of Confucianism in the art design education of colleges and universities, it is proposed to adjust the curriculum structure system scientifically, to show the characteristics of art design education; to increase the relevant elective courses appropriately, to learn the excellent connotation of Confucianism; to emphasize the introduction of excellent teachers, Guiding the actual value and to carry out the activities of Confucian ideology and art, to enhance the students' comprehensive practical ability and other related teaching suggestions.
\end{abstract}

\section{Introduction}

Confucianism is the core idea of Chinese traditional culture, which has an important influence on the development of society. Confucianism has many outstanding ideological essence, the Confucianism into the art and design education in colleges and universities, to highlight the characteristics of Chinese art education, more ethnic elements into the art design process, in the nation and the development of the supply . Based on the actual situation of art design education in colleges and universities, this paper puts forward some related concepts and teaching suggestions, hoping to have some reference significance for art design education in colleges and universities.

\section{The Value of Confucianism in Art Design Education in Colleges and Universities}

2.1 Help to explore the modern design education concept, reconcile the ancient and modern positive factors

The core content of Confucian culture is "the doctrine of the mean", "the doctrine of the mean" on the development of the Chinese nation had an important impact [1]. In the context of the current development of the times, many students are easy to "moderation" have a certain misunderstanding that the doctrine of the doctrine is eclectic, but not the case. The doctrine of the mean refers to the coordination of differences, to ensure harmony and unity [2]. As far as art education is concerned, the implication of the doctrine of the mean for art education is that it needs correct attitude in art design education, face up to the connotation of the times and national traditions, and take its essence away from its dregs. In the art design needs to pay more attention to Chinese and foreign content, cultivate students to form the correct ideas and values.

2.2 Help to cultivate the cultural quality of students, highlighting the national characteristics of design elements

Modern design is no longer just a product, but represents an era, a kind of thought and an environment. People's ideas, the environment, and so has become an important component of modern art design elements. Confucianism into the modern art design, help to cultivate students' cultural quality, so that students can have a good traditional cultural ideas, learning the essence of outstanding ideas, Confucianism as a student rich cultural support, highlighting the College of Art and Design Education The characteristics of artistic design education, academic disciplines become more prominent, clear positioning of art design education concept [3]. This way not only to highlight the national characteristics of design elements, while the development of China's traditional culture and art can also have an important impact. 


\section{How to Integrate Confucianism into Art Design Education in Colleges and Universities}

In the university art design education, we can adjust the curriculum structure system scientifically to show the characteristics of the art design education; appropriately increase the relevant elective courses, learn the excellent connotation of Confucianism; pay attention to the introduction of excellent teachers, show the actual value of education and guidance; Art activities, enhance the comprehensive practical ability of students, etc., will be cleverly integrated into the Confucian art design education, for students to create a flexible platform for self-show, tap the potential of students more potential.

3.1 Scientifically adjust the curriculum structure system, show the characteristics of art design education

The characteristics of the art and design specialty determine the cultural pattern of the art design education system. In the current development background, more creative talents are needed, and the innovation is the soul of design [4]. Confucian thought and culture as the dominant thought of the development of the Chinese nation for a long time, including a large number of cultural heritage, can bring more design inspiration for the students, art design can be the characteristics of the times and national characteristics of the integration of student art design as a whole The effect of the upgrade can have a positive impact.

In the current university art design education activities, the need to adjust the structure of the curriculum system, optimize the curriculum teaching mode, and strive to cultivate more "compound" talent. Art and Design is a relatively flexible features, fashion characteristics of the subject, therefore in the teaching mode and course setting process, can not be too rigid, the need to build an open curriculum teaching mode, focus on mining students creative ability, for the Students to create a flexible platform for self-expression, tap the potential of students more potential.

For example, in the course of curriculum design, the specialty of art design in colleges and universities can integrate disciplinary, interdisciplinary, interdisciplinary and interdisciplinary, and optimize the structure of the course based on the connotation of Confucianism and ideology. ".

3.2 Appropriate to increase the relevant elective courses, learning the excellent connotation of Confucian thought

Artistic design education in college students to enhance the overall cultural quality, requires a lot of knowledge to support. The university can appropriately increase the Confucianism-related elective courses or lectures, so that students can have the place of Confucian thought learning, feel the excellent connotation of Confucianism, and guide students to actively study the spirit of Confucianism, feel the charm of traditional culture, The traditional cultural elements and artistic design activities, the effective integration of Confucianism in the feelings of culture, "broad and profound" at the same time, can also get more ideological inspiration.

Modern education, especially undergraduate, is general education. However, under the circumstances of intense and appropriate development, higher requirements are put forward for art design students in colleges and universities. Under the current development background, students are required to strengthen the related discipline learning, integrate multidisciplinary knowledge and information collection, [5]. The infiltration of disciplines can be carried out through the establishment of courses related to the Confucian culture, integrating the results of the existing local cultural studies into the curriculum system, integrating the cultural theory with the artistic design activities, and integrating the students' comprehensive abilities Enhance the lay a good foundation.

3.3 Pay attention to the introduction of outstanding teachers to show the actual value of education and guidance

Under the background of multicultural era, the individual professional accomplishment, comprehensive ability and design level of the teachers of art design in colleges and universities are gradually improved. In order to deepen the understanding of the connotation of Confucianism and culture, it is necessary to guide the students to understand the Confucianism and to give students appropriate thinking and inspiration. In the process of teaching, So that each student can be applied to the flexibility of Confucian ideas to their own art and design activities. 
Art design teachers need to have a high professional level, with comprehensive ability of interdisciplinary education. Teachers need to strengthen the study of Confucianism, the core of Confucian culture and ideological spirit in the course of teaching activities, Confucianism cleverly integrated into the art design teaching activities, so that students can experience the national nature of curriculum teaching and the times Features. Thinking guide, teachers need to actively guide students to learn Confucian culture, feel the Confucian culture, encourage students to speak boldly, and actively innovate.

The school also needs to introduce more excellent teachers to improve the overall quality of art design in colleges and universities, and to ensure the overall quality of art design and teaching, and to pay attention to the development of students' comprehensive quality.

3.4 To carry out the activities of Confucian ideology and art, to enhance the students' comprehensive practical ability

Art design has a certain practical characteristics, the ability of students to a higher comprehensive practice. The university can set up a platform for students to display their practice through the way of carrying out the artistic activities of Confucianism, and at the same time, can make more students pay attention to the Confucian ideology and culture.

Such as the school can be "approached Confucius, feelings of China" as the theme, the visual arts and design for the form of expression, to carry out art and design activities. Students can create art based on their own understanding. Students can be completed after the creation of competitions, through a variety of ways to promote the comprehensive development of students.

\section{Summary}

Confucianism into the art and design education in colleges and universities, help to explore the concept of modern design education, reconcile ancient and modern positive factors, cultivating students' cultural qualities, highlighting the national characteristics of design elements. Under the background of the current development of the times, art design education activities in colleges and universities can show the characteristics of art design education through scientific adjustment of the curriculum structure system; appropriately increase the relevant elective courses to learn the excellent connotation of Confucianism; pay attention to the introduction of excellent teachers, And to carry out the activities of Confucian ideology and arts, to enhance students' comprehensive practical ability, etc., to guide students to learn Confucian ideology and culture, feelings of Confucianism and culture, to bring more design inspiration for students, art design to the times and national characteristics Characteristics, integration, and promote the overall ability of students to improve art and design.

\section{References}

[1] YIN Yun-chao.National Cultural Value of Confucianism in Art Design Education: A Case Study of Art Design Major in Shandong University [J].

[2] Yu Xiao.Tradition and development of traditional arts and crafts in local colleges and universities art education - A case study of Qiong kiln [J].

[3] Cheng Hao, Sun Shaokun.Analysis of art and art design in colleges and universities of bottlenecks and breakthroughs in strategy [J] Xue Weekly, 2015,05 (23): 229 +63.

[4] Xu Yaodong, Shao Xiaofeng. Creative talent training is the key to cultural and creative industries - art design education in colleges and universities [J]. Fujian Forum (Humanities and Social Sciences), 2015,06 (15): 130-133.

Journal of Nantong Vocational \& Technical Institute of Aeronautics and Astronautics, 2011,01 (14): 118-102. [5] CHEN Hui. Inspirations of "learning-guided multiple interaction" teaching model for art design education in colleges and universities - Visual communication design teaching as an example [J]. -121 . 